\title{
The Frequency and Neuroimaging Characteristics of Macro- and Giant Pituitary Adenomas
}

\author{
Yulduz M. Urmanova, $\mathrm{PhD}, \mathrm{ScD}^{1 *}$; Salimjon P. Sodikov, $\mathrm{PhD}^{2}$; Minji Kim ${ }^{1}$; \\ Temur A. Duschanov ${ }^{3}$; Shakhnoza Sh. Mukhtarova ${ }^{1}$ \\ ${ }^{1}$ Tashkent Medical Pediatric Institute, Tashkent \\ ${ }^{2}$ Medical Center «Sodikov Salimjon Pardaevich», Samarkand region, Loyish \\ ${ }^{3}$ The Republican Scientific Center for Emergency Medical Aid, Tashkent \\ The Republic of Uzbekistan
}

\begin{abstract}
Data from 3 medical centers of Tashkent city, in which 156 patients (76 men and 80 women) with pituitary macroadenomas (PMA) and iant pituitary adenomas (GPA) were treated during 3 years (between 2015 and 2017), were retrospectively analyzed. The results of the study showed that the different variants of PMA/GPA suprasellar growth might serve as a neuroimaging marker of tumor aggressiveness, namely, supra-infra-latesellar and supra-infra-tellular growth observed in 68 (43.5\%) patients, as well as invasive tumor growth in $108(69.2 \%)$ patients. Transsphenoidal removal is a relatively safe and effective method, even in PMA and GPA with suprasellar extensions, in most of the cases.(International Journal of Biomedicine. 2019;9(1):72-74.)
\end{abstract}

Key Words: giant pituitary adenomas $\bullet$ pituitary macroadenomas $\bullet$ magnetic resonance imaging $\bullet$ transsphenoidal hypophysectomy

\section{Abbreviations}

GPA, giant pituitary adenomas; NFPA, non-functioning pituitary adenoma; PA, pituitary adenomas; PMA, pituitary macroadenomas; PG, the pituitary gland; SIR, Standardized Incidence Rates; TSHS, transsphenoidal hypophysectomy.

\section{Introduction}

Pituitary adenomas constitute $10 \%-15 \%$ of intracranial tumors, and occur in $17 \%-25 \%$ of the population. ${ }^{(1)}$ Most pituitary adenomas are benign, but approximately one third of them are invasive, encroaching upon the bones, dura, and/or other adjacent structures. ${ }^{(2,3)}$ Functioning PMA and GPA have large growth volumes and endocrinological abnormalities. Pituitary adenomas are classified as "giant" when their diameter exceeds $4 \mathrm{~cm} \cdot{ }^{(4)} \mathrm{GPA}$ has the potential for widespread, multi-directional extension. These tumors are very difficult to treat and can behave aggressively. ${ }^{(5,6)}$

*Corresponding author: Yulduz Urmanova, PhD, ScD. Tashkent Medical Pediatric Institute. Tashkent, Uzbekistan. E-mail: yulduz. urmanova@mail.ru
According to M. Gruppetta and J. Vassallo, ${ }^{(7)}$ the prevalence for macroadenomas was 40-67/100 000 people and the SIR was 1-90/100 000/year. Giant pituitary adenomas ( $>40 \mathrm{~mm}$ ) constituted $4-8 \%$ of the whole cohort of PAs and the SIR was 0-18/100 000/year. In 2004, WHO ${ }^{(4)}$ classified pituitary adenomas into typical adenomas, atypical adenomas, or carcinomas.

Various classifications have been proposed but there is no evident terminology to describe large pituitary tumors. ${ }^{(8)} \mathrm{JC}$ Zakir et al. showed that parasellar invasion prevails as a strong predictive factor for tumor recurrence. ${ }^{(9)}$ Severe suprasellar extension should be considered as invasion parameter and could impact prognosis.

An original study comparing the clinical spectrum of giant prolactinomas with ordinary macroprolactinomas was performed by Espinosa and colleagues. ${ }^{(10)}$

Despite the histological benign nature, the management 
of PMA and GPA is very difficult. (6,7,11-17) Transsphenoidal surgery is recognized as the optimum technique for the management of pituitary adenomas, as it helps preserve normal pituitary function and allows recovery of visual function. ${ }^{(6,18,19)}$ As a consequence, the transsphenoidal approach is the first choice in the surgical treatment of MPA or GPA with suprasellar extensions. ${ }^{(6,20-22)}$

The purpose of this study was to determine the frequency and neuroimaging characteristics of macro- and giant pituitary adenomas according to seeking medical care.

\section{Materials and Methods}

We retrospectively analyzed data from 3 medical centers of Tashkent city (RSSPMC of Endocrinology, the Republican Research Center of Neurosurgery, and the Republican Scientific Center for Emergency Medical Aid), in which 156 patients (76 men [mean age of 37.1 years] and 80 women [mean age of 38.2 years]) with PMA and GPA were treated during 3 years (between 2015 and 2017). The duration of the disease ranged from 2 months to 25 years. As the surgical management, TSHS was performed in 137 (87.8\%) cases (surgeons: R.B. Fayzullaev, MD, PhD; Akbutaev MD; Prof. K. I. Makhkamov, MD, PhD; Prof. Michael Powell, MD, $\mathrm{PhD})$ with repeated operations in $8(5.1 \%)$ cases. Six $(3.8 \%)$ patients received radiotherapy and 1 - chemotherapy.

Methods of investigation included: 1) general clinical examination, assessment of endocrine/neurological status; 2) instrumental methods of examination (visual field perimetry, colour vision, fundus oculi, visual acuity, ECG, CT/MRI of sella turcica and adrenal glands, ultrasound of reproductive organs); 3) determination of blood hormones (GH, IGF1, LH, FSH, PRL, TTG, ACTH, testosterone, estradiol, prolactin, progesterone, cortisol) in RIA using "Gamma-12" and "Strantg 300," and 4) histological examination of postoperative specimens.

Statistical analysis was performed using statistical software package SPSS version 20.0 (SPSS Inc, Chicago, IL). Categorical variables were analyzed using the Chi-square test. A probability value of $P \leq 0.05$ was considered statistically significant.

\section{Results}

Depending on the size of PA detected on CT/MRI, the patients were divided into two groups: Group 1 included 70/44.9\% patients with PMA (from $20 \mathrm{~mm}$ to $30 \mathrm{~mm}$ in maximum diameter), Group 2 - 86/55.1\% patients with GPA ( $\geq 40 \mathrm{~mm})$. Table 1 presents the distribution of patients by sex and age. In accordance with the topographic-anatomical classification by B. Kadashev, ${ }^{(23)}$ endosellar adenomas were detected in 38/24.4\% cases and endosuprasellar in $5 / 3.2 \%$ cases, both of which were characterized by chiasmatic syndrome. Endo-supra-infra-ante-latero-retrosellar adenomas were detected in 48/30.7\% cases, of which 3 were with extension into the anterior cranial fossa, 5 - into the ventricles, 1 - into the cavernous sinus, 2 - into both cavernous sinus and the middle cranial fossa. This group of adenomas contributed to the development of various neuro-endocrine disorders, as well as pyramidal symptoms due to affection of the motor path.
Table 1.

The age-gender distribution of patients

\begin{tabular}{|l|c|c|c|c|}
\hline \multirow{2}{*}{ Age, years } & \multicolumn{2}{|c|}{ Number of men } & \multicolumn{2}{c|}{ Number of women } \\
\cline { 2 - 5 } & Group 1 & Group 2 & Group 1 & Group 2 \\
\hline 13 & - & - & 1 & 1 \\
\hline $16-29$ & 8 & 14 & 10 & 10 \\
\hline $30-44$ & 10 & 15 & 13 & 10 \\
\hline $45-59$ & 8 & 13 & 12 & 11 \\
\hline $60-74$ & 3 & 5 & 4 & 5 \\
\hline$\geq 75$ & - & - & 1 & 2 \\
\hline Total: $\mathrm{n}=156$ & 29 & 47 & 41 & 39 \\
\hline
\end{tabular}

Infra-supra-laterosellar and infra-suprasellar adenomas were detected with the same frequency - 28/17.9\% cases. These cases had more vivid clinical symptoms due to the direction of tumor growth. Disorders of nasal breathing and swallowing (dysphagia) were characteristic of patients with these adenomas.

The distribution of tumors in the sellar region is presented in Table 2. Thus, NFPA was the most frequent type $(96 / 61.5 \%)(P<0.05)$, whereas somatotropinoma and prolactinoma numbered $23 / 14.7 \%$ and $20 / 12.8 \%$, respectively. Itsenko-Cushing's disease was detected in two cases $(1.3 \%)$.

Table 2.

The distribution of patients according to the sellar region tumors and treatment

\begin{tabular}{|l|c|c|c|c|c|c|}
\hline \multirow{2}{*}{ Nosology } & \multicolumn{2}{|c|}{$\begin{array}{c}\text { Number of } \\
\text { patients }\end{array}$} & \multicolumn{2}{c|}{ TSHS } & \multicolumn{2}{c|}{$\begin{array}{c}\text { Radiation } \\
\text { therapy }\end{array}$} \\
\cline { 2 - 7 } & $\begin{array}{c}\text { Group } \\
1\end{array}$ & $\begin{array}{c}\text { Group } \\
2\end{array}$ & $\begin{array}{c}\text { Group } \\
1\end{array}$ & $\begin{array}{c}\text { Group } \\
2\end{array}$ & $\begin{array}{c}\text { Group } \\
1\end{array}$ & $\begin{array}{c}\text { Group } \\
2\end{array}$ \\
\hline NFPA & 43 & $\begin{array}{c}53 \\
\left(6^{*}, 3^{\wedge}\right)\end{array}$ & 31 & $\begin{array}{c}45 \\
(5 \#)\end{array}$ & $\begin{array}{c}1 \\
(1 \#)\end{array}$ & 8 \\
\hline Craniopharyngioma & 3 & $\begin{array}{c}9 \\
\left(2^{*}, 2^{\wedge}, 1 \#\right)\end{array}$ & 3 & 6 & - & 1 \\
\hline Somatotropinoma & 11 & $\begin{array}{c}12 \\
\left(2^{*}\right)\end{array}$ & 8 & 10 & - & 2 \\
\hline Prolactinoma & 12 & $\begin{array}{c}8 \\
\left(3^{*}, 1^{\wedge}\right)\end{array}$ & 11 & 5 & - & - \\
\hline Hemangioblastoma & - & 1 & - & $\begin{array}{c}1 \\
(1 *, 1 \#)\end{array}$ & - & 2 \\
\hline $\begin{array}{l}\text { Itsenko-Cushing's } \\
\text { disease }\end{array}$ & 2 & - & 1 & - & - & - \\
\hline Astrocytoma & - & $\begin{array}{c}1 * \\
\left(1^{*}\right)\end{array}$ & - & $\begin{array}{c}1 \\
(1 \mathrm{CT})\end{array}$ & - & 1 \\
$(1 \mathrm{ChT})$
\end{tabular}

*-tumor regrowth, ^^- hemorrhage in stroma, \#- reoperation, ChTchemotherapy, CT-combination therapy, TSHS - transsphenoidal hypophysectomy.

According to MRI, necrosis of PG was diagnosed in one patient, hemorrhage in PG - in $6 / 3.8 \%$ cases. In 14 GPA patients, tumor growth continued after its removal. Malignant type of NFPA was detected in 2 patients. 
Based on MRI of PG and X-ray classification by I.I. Dedov, ${ }^{(24)}$ MPA with suprasellar growth were distributed as follows:

- Suprasellar growth within $10 \mathrm{~mm}$ above the pituitary fossa - 40 cases

- Suprasellar growth within $20 \mathrm{~mm}$, with extension into the front pocket of the third ventricle (large PA) - 30 cases

- Suprasellar growth up to $30 \mathrm{~mm}$, fills the anterior part of the third ventricle (very large PA) - 50 cases

- Suprasellar growth $>30 \mathrm{~mm}$ (massive PA), rises above the level of the Monroe hole, or previous adenomas with asymmetrical lateral or multiple-sided growth (massive PA) -36 cases

GPA showed invasive growth into surrounding anatomical structures in $69.2 \%$ of cases and pituitary apoplexy in $3.8 \%$ of cases, which was the main factor limiting the radical surgical capabilities and increasing the number of relapses.

In conclusion, the different variants of PMA/GPA suprasellar growth might serve as a neuroimaging marker of tumor aggressiveness, namely, supra-infra-latesellar and supra-infra-tellular growth observed in 68 (43.5\%) patients, as well as invasive tumor growth in 108 (69.2\%) patients. Transsphenoidal removal is a relatively safe and effective method, even in PMA and GPA with suprasellar extensions, in most of the cases.

\section{Competing Interests}

The authors declare that they have no competing interests.

\section{References}

1. Asa SL, Ezzat S. The pathogenesis of pituitary tumours. Nat Rev Cancer. 2002;2(11):836-49.

2. Scheithauer BW, Kovacs KT, Laws ER Jr, Randall RV. Pathology of invasive pituitary tumors with special reference to functional classification. J Neurosurg. 1986;65(6):733-44.

3. Colao A, Grasso LF, Pivonello R, Lombardi G. Therapy of aggressive pituitary tumors. Expert Opin Pharmacother. 2011;12(10):1561-70.

4. Lloyd RV, Kovacs K, Young WF Jr., et al. Pituitary tumours introduction. In: DeLellis RA, Lloyd RV, Heitz PU, Eng C, editors. Tumours of the Pituitary, Chapter 1. Pathology and Genetics of Tumours of Endocrine Organs. Lyon, Paris: World Health Organization Classification of Tumours. IARC Press; 2004.

5. Shrivastava RK, Arginteanu MS, King WA, Post KD. Giant prolactinomas: clinical management and long-term follow up. J Neurosurg. 2002;97(2):299-306.

6. Goel A, Nadkarni T, Muzumdar D, Desai K, Phalke U, Sharma P. Giant pituitary tumors: a study based on surgical treatment of 118 cases. Surg Neurol. 2004;61(5):436-45; discussion 445-6.

7. Gruppetta M, Vassallo J. Epidemiology and radiological geometric assessment of pituitary macroadenomas: populationbased study.Clin Endocrinol (Oxf). 2016;85(2):223-31. doi: 10.1111/cen. 13064 .

8. Garibi J, Pomposo I, Villar G, Gaztambide S. Giant pituitary adenomas: clinical characteristics and surgical results. Br J Neurosurg. 2002;16(2):133-9.

9. Zakir JC, Casulari LA, Rosa JW, Rosa JW, de Mello PA, de Magalhães AV, Naves LA. Prognostic Value of Invasion, Markers of Proliferation, and Classification of Giant Pituitary Tumors, in a Georeferred Cohort in Brazil of 50 Patients, with a Long-Term Postoperative Follow-Up. Int J Endocrinol. 2016;2016:7964523. doi: 10.1155/2016/7964523.

10. Espinosa E, Sosa E, Mendoza V, Ramírez C, Melgar V, Mercado M. Giant prolactinomas: are they really different from ordinary macroprolactinomas? Endocrine. 2016;52(3):652-9. doi: 10.1007/s12020-015-0791-7.

11. Chohan MO, Levin AM, Singh R, Zhou Z, Green CL, Kazam JJ, Tsiouris AJ, Anand VK, Schwartz TH. Three-dimensional volumetric measurements in defining endoscope-guided giant adenoma surgery outcomes. Pituitary. 2016;19(3):311-21. doi: 10.1007/s11102-016-0709-2.

12. Graillon T, Castinetti F, Fuentes S, Gras R, Brue T, Dufour $H$. Transcranial approach in giant pituitary adenomas: results and outcome in a modern series. J Neurosurg Sci. 2017 Jan 12. doi: 10.23736/S0390-5616.16.03889-3.

13. Han S, Gao W, Jing Z, Wang Y, Wu A. How to deal with giant pituitary adenomas: transsphenoidal or transcranial, simultaneous or two-staged? J Neurooncol. 2017;132(2):313321. doi: 10.1007/s11060-017-2371-6.

14. Landolt AM. History of pituitary surgery. In: Greenblatt $\mathrm{SH}$, ed. A History of Neurosurgery. In its Scientific and Professional Contexts. Park Ridge, IL. American Association of Neurological Surgeons; 1997:373-400.

15. Landolt AM. Transsphenoidal surgery of pituitary tumors: its pitfalls and complications. Prog Neurol Surg. 1990;13:1-30. 16. Laws ER Jr, Ebersold MJ. Pituitary apoplexy--an endocrine emergency. World J Surg. 1982;6(6):686-8.

17. Landeiro JA, Fonseca EO, Monnerat AL, Taboada GF, Cabral GA, Antunes F. Nonfunctioning giant pituitary adenomas: Invasiveness and recurrence. Surg Neurol Int. 2015;6:179. doi: 10.4103/2152-7806.170536. eCollection 2015.

18. Black PM, Zervas NT, Candia G. Management of large pituitary adenomas by transsphenoidal surgery. Surg Neurol. 1988;29(6):443-7.

19. Mortini P, Barzaghi R, Losa M, Boari N, Giovanelli M. Surgical treatment of giant pituitary adenomas: strategies and results in a series of 95 consecutive patients. Neurosurgery. 2007;60(6):993-1002; discussion 1003-4.

20. Saito K, Kuwayama A, Yamamoto N, Sugita K. The transsphenoidal removal of nonfunctioning pituitary adenomas with suprasellar extensions: the open sella method and intentionally staged operation. Neurosurgery. 1995;36(4):66875; discussion 675-6.

21. Hashimoto N, Handa H, Yamashita J, Yamagami T. Long term follow-up of large or invasive pituitary adenomas. Surg Neurol. 1986;25(1):49-54.

22. Matsuyama J, Kawase T, Yoshida K, Hasegawa M, Hirose Y, Nagahisa S, Watanabe S, Sano H. Management of large and giant pituitary adenomas with suprasellar extensions. Asian J Neurosurg. 2010;5(1):48-53.

23. Kadashev BA. Pituitary adenomas: clinic, diagnosis, treatment M., 2007. [In Russian].

24. Dedov AI, Belenkov YuN, Belichenko OI, Melnichenko GA. Magnetic resonance imaging in the diagnosis of diseases of the hypothalamic-pituitary system and adrenal glands. M .: Meditsina, 1997. [In Russian]. 